\title{
Texas is not a human evolution desert! Presenting human evolution to the public through museum displays
}

\author{
Shelley L. Smith ${ }^{*}$ (D)
}

\begin{abstract}
Texas is home to four of the largest metropolitan areas in the U.S. As would be expected, several large universities in Texas, public and private, offer courses in which the topic of human evolution is covered. What might be more surprising to some, given the politics of the state, is that two major Texas public museums (the Houston Museum of Natural Science and the Perot Museum of Nature and Science in Dallas) display substantial human evolution content. Here I review content related to human evolution in five major science museums in Texas and explore the reasons for the differences among these museums. Among the most important factors are money, museum location, museum history and mission, and what can be called "intentionality." Unsurprisingly, if we want to see more human evolution museum displays, we must convince museum administrators that adding this content is consistent with their mission and will attract more visitors. We (and our students) can, in addition, be more proactive in reaching out to our local museums.
\end{abstract}

Keywords: Natural history/science museums, Paleoanthropology, Human origins, Museum exhibits

\section{Introduction}

Texas is well known as a politically conservative state with several liberal pockets in major urban centers. The term of the last democratic governor, Ann Richards, ended in January 1995. Both current U.S. Senators from Texas (John Cornyn and Ted Cruz) are republicans. Structural equation modeling has demonstrated a greater linkage between conservative politics and fundamentalist religious beliefs in the U.S. than in nine European countries; fundamentalist beliefs, in turn, have been shown to be associated with less acceptance of evolution, particularly in the U.S. (Miller et al. 2006).

Several of the largest cities in the U.S. are located in Texas. According to U.S. Census estimates for Metropolitan Statistical Areas (U.S. Census http://www.factfinder

*Correspondence: slsmith@uta.edu

Department of Sociology and Anthropology, University of Texas

at Arlington, Box 19599, Arlington, TX 76019, USA .census.gov), the Dallas-Fort Worth-Arlington MSA ranks fourth, Houston-The Woodlands-Sugar Land ranks fifth, San Antonio-New Braunfels ranks 24th, and Austin-Round Rock ranks 30th. Combined, these MSAs contain more than 19.2 million people. Furthermore, Texas is second only to California in total population, which is a major reason these two states drive the textbook market (Collins 2012). The nature and extent of evolution content in pre-college textbooks is partially market-driven, and Texas has long been a battleground state for the evolution-creationism controversy in public education. The Texas State Board of Education periodically debates the details of curriculum standards (see, e.g., the Texas Freedom Network http://www.tfn.org), including evolution content.

Beyond the classroom, museums offer an important venue for introducing the public to evolution and potentially influencing the curricular debate over evolution. Texas is fortunate to have several prominent natural 
history and science museums that display evolution and paleontology content. Dallas, Fort Worth, Houston, and San Antonio all have major natural history or science museums. Austin is the site of the Texas Memorial Museum, located on the campus of UT Austin.

The Houston Museum of Natural Science has a dedicated space for human evolution within its large $(30,000$ sq. ft.) Morian Hall of Paleontology (Paul Bernhard Exhibit Design http://www.pbexhibits.com). The Perot Museum of Nature and Science in Dallas, a derivative of the Dallas Museum of Natural History that opened in December 2012, has already renovated its Being Human Hall and expanded the human evolution content within it. In addition, the Perot has founded a Center for the Exploration of the Human Journey and hired curator Dr. Becca Peixotto to head it. At the time of this writing (October 2019), a temporary exhibit of South African hominins is on display. In contrast to the Perot Museum, the Fort Worth Museum of Science and History has no human evolution content on display; while dates in millions of years and geologic periods and eras are clearly marked, "evolution" is not highlighted in the Fort Worth museum. San Antonio's Witte Museum has a clear focus on "Deep Time" but no human evolution content is on display in the permanent galleries. UT Austin's Texas Memorial Museum was formerly one of several U.S. sites for the NSF-funded Explore Evolution exhibit. This exhibit, with content from the small (HIV) to the large (whales), included a human evolution component. The Texas Memorial Museum no longer has this (or any other) human evolution content on display.

Below I briefly review the human evolution content (or lack thereof) in these museums. I propose that the most important reasons for the differences among these museums are money, museum location, museum history and mission, and what Mr. Charles Walter (Mayborn Museum, Baylor University, Waco, Texas, personal communication) has referred to as "intentionality." Although politics may play an important role in connection with money, I submit that the presence or absence of human evolution content is not determined directly by the politics of the state of Texas.

\section{The Houston Museum of Natural Science}

In 2007, the Houston Museum of Natural Science hosted the traveling exhibit, Treasures of Ethiopia. The star attraction was "Lucy" (Australopithecus afarensis). As is well known, hosting this exhibit was controversial because the original fossil material traveled outside of Ethiopia (Berger 2007; Breal 2007; Driver 2007; Rhor $2007 \mathrm{a}, \mathrm{b})$. This exhibit preceded the opening of the Morian Hall of Paleontology in 2012.
The Morian Hall's primary scientific advisor is the well-known and somewhat eccentric dinosaur expert Dr. Robert Bakker. His interesting sense of humor is evident throughout the hall. Parts of the exhibit are strikingly beautiful, reminiscent of an art museum. The curator with the responsibility for leading the design of the human evolution area was an archaeologist, Dr. Dirk Van Tuerenhout. Dr. Van Tuerenhout continues to oversee almost all anthropology-related content in the museum (with the exception of the Egyptian gallery), including traveling exhibits. He was the lead curator for the Treasures of Ethiopia exhibit.

Dr. Van Tuerenhout consulted with several archaeologists and paleoanthropologists when designing the human evolution portion of the Morian Hall (personal communication). There is an abundance of text, with 24 named species (not including Denisovans) in a long series of backlit murals along one side of the exhibit. Four bust reconstructions by paleoartist Mr. Viktor Deak (Sahelanthropus tchadensis, Au. afarensis, Homo habilis, and Homo neanderthalensis), popular with visitors for selfies, are placed on the opposite side of the gallery; each bust is accompanied by a cranial reproduction for each species. A phylogenetic-tree-like display of Bone Clones cranial reproductions in a large case is placed at the end of this sequence. A panel display located near the case of cranial reconstructions has a series of ovals with artistic images of related primates and hominins.

Stone tools, including many from Texas sites, are prominently displayed. A mammoth, mastodon and human cast skeletons take center stage. One human skeleton is posed with an atl-atl; another, holding a flickering torch, is mounted in a simulated cliff drive. A third, an apparently unfortunate hunting participant, is suspended from the ceiling in a flailing posture. On entry or exit to the space (depending on whether one is going forward or backward in time), images from Chauvet are projected on a wall; across from this wall, a case contains full skeletal reproductions of $A u$. afarensis ("Lucy"), a chimpanzee, and a human. Carts within the space contain more Bone Clones reproductions and cultural artifacts.

The exhibit is fairly comprehensive and I was impressed that the designers managed to get climate change (on a text panel) and human evolution content displayed together in the same space. The exhibit is both entertaining and informative. My main complaint is that there are no actual casts of the hominin fossils. With the monetary might of this museum, casts could have been purchased. At the time of the construction of this exhibit, no museum could purchase casts directly from Ethiopia, but many museums display casts produced by the National Museums of Kenya, among others. According to Dr. Van Tuerenhout (personal communication), obtaining casts 
from Kenya would not have been possible due to paleopolitical constraints brought about by the decision of the museum to host the Treasures of Ethiopia exhibit.

Regardless of the reason, the lack of high-quality cast materials in such a prominent U.S. museum is unfortunate. Concerted efforts should be made by researchers and their affiliated institutions to share casts and other resources with museums worldwide as a public good in order to promote science education. With due recognition of the importance of allowing sufficient time for initial analysis and description, high-quality casts should be made available upon request as soon as possible to museums seeking to purchase them, regardless of the status or personal contacts of the curators. Nonetheless, while research-quality casts are preferable in museum displays because they more accurately represent the detailed morphology of the fossils, display of less expensive, lowerquality reproductions is in my opinion acceptable if there is no other alternative for monetary or other reasons. Such lack of access should not preclude an exhibit.

A more minor and more personal complaint is that the species splitting in the Houston exhibit is excessive and somewhat confusing. For example, the esoteric species Homo gautengensis (Curnoe 2010) is mentioned on the $A u$. sediba panel. Furthermore, the Bone Clones display case appears visually cluttered, and a studious visitor could potentially become confused or frustrated by the detailed presentation. With so many species names listed, it is easy to misassociate taxonomic names with their respective mounted reproductions. However, despite these quibbles, I grant that it is hard to miss the point that there is an abundance of hominins, a point which is good to convey to a museum-going audience.

\section{The Perot Museum of Nature and Science}

Although the Perot is a new museum, the Dallas Museum of Natural History dates back to 1935, having been founded in conjunction with the Texas Centennial celebration (1936) in Fair Park (Davis 2016). The Perot, located in downtown Dallas, was established following a 2006 merger with two museums that focused more on children, The Science Place and the Dallas Children's Museum (Perot Museum of Nature and Science http:// www.perotmuseum.org). The original Fair Park venue of the Dallas Museum of Natural History is now closed.

The human evolution content in the museum is located within the Being Human Hall. The original Being Human Hall had very limited human evolution content. While evolution content in general is prominent at the Perotthe word can be seen in large letters from the escalatorthe main focus of the Being Human Hall's first iteration was medical. There was (and still is) a close connection with the UT Southwestern Medical School and its associated research center. The original version of the hall had a tower with photographs of Bone Clones images of crania and a small table-top display with information on the Laetoli footprints. Humans were included in Tree of Life and comparative anatomy displays, and a very-easilymissed and incomplete panel display, "Rummage through Evolution's Attic," described human anatomy "leftovers."

Mr. Dan Kohl, who held various titles at the museum, including serving as the interim CEO, selected the Being Human Hall for an early renovation (personal communication). Even before this major renovation, but after Dr. Lee Berger had spoken to sell-out crowds about the Rising Star hominins, four full-body fleshed reproductions by paleoartist Ms. Elisabeth Daynès were introduced into the hall in December of 2015 (Daynès http://www.dayne s.com). Later, cranial, hand, and foot reproductions of Homo naledi, donated to the museum by Dr. Berger, were added to the exhibit.

Consulting with advisors from UT Southwestern among others, Mr. Kohl selected five characteristics to focus on in the new hall: walking, hands, brains, faces, and voices. DNA and genetics is another highlighted area, integrated with UT Southwestern research. The human origins component, the Becoming Human wall, anchors the exhibit by providing historical context. Original artwork and mounted, touchable cranial reproductions introduce visitors to six hominins: Ardipithecus ramidus, Australopithecus afarensis, Paranthropus robustus, Homo habilis, Homo erectus, and Homo neanderthalensis. Three of the original four Daynès full-body reproductions remain on display. Replicas of fossils (e.g., Bone Clones "Ardi" hand and foot bones) and tools, and some original tools on loan, have been added.

The new hall highlights UT Southwestern research as well as focusing on the South African Homo naledi fossils and the research of Dr. Berger and his team. Five Nobel prizes won by UT Southwestern researchers remain on display from the previous hall. A new, illuminated highlight is a dissected brain and spinal cord suspended in fluid. The hall has artistic and cultural elements, including face masks, related to the unique and expressive faces of humans.

In character with the hands-on, science-center ambience of this museum, there is an abundance of touchscreen monitors and other activities. One monitor has simulations of humanity's variation and migration through time. The California Academy's simulation of a walking $A u$. afarensis, chimpanzee, and human appears in large-screen format along the human evolution wall. Visitors can explore Rising Star Cave in a virtual reality experience with the aid of museum staff. Inside the hall's BioLab, one activity is focused on determining 
maturational age (child vs. adult) of fossil hominin remains, using cranial and dental evidence from Homo naledi.

In conjunction with the opening of the new Being Human Hall, the Perot founded a Center of Excellence, the Center for the Exploration of the Human Journey, in 2018. They hired Dr. Becca Peixotto to head this Center. (Previously, only two PhD-level scientists, both dinosaur paleontologists, were members of the museum staff. In 2016, Dr. Rose Jones, a medical anthropologist, was hired as Director of Evaluation.) Dr. Peixotto was not in residence for the Being Human Hall renovation; she arrived around the time that the renovated hall opened (officially, just after). Not having been developed under the supervision of an anthropologist, the Perot's exhibit has a unique blend of elements and a different approach to the subject matter.

Beginning fall 2019 (October 2019-March 2020), the Perot is hosting a temporary exhibit, Origins. Fossils from the Cradle of Humankind, focusing on Homo naledi and Australopithecus sediba. A major emphasis is placed on teamwork and the varied skills that contribute to the study of paleoanthropology, with a goal of attracting young people to this science. "In the spotlight" vignettes highlight the roles of a diversity of researchers. In one part of the exhibit, student researchers are visible through glass, working on computers. One monitor is turned outward, visible to visitors.

In the introductory video and on a text panel, it is emphasized that human evolution is not a progressive ladder, and even tree metaphors are problematic. Instead, the "braided stream" metaphor is favored. Dotted circular outlines around crania of various species depict this concept visually. In a central area, a circular video tower plays recordings of team members describing their roles in recovery. Text panels and displays give a sense both of the difficulty of recovery at Rising Star and also of adventure.

Two separate guarded rooms, one near the beginning of the exhibit and one near the end, house the remains of the type specimen of $A u$. sediba ("Karabo") and the partial skeleton and a new Daynès full-body reproduction of a Homo naledi individual ("Neo"). The latter space leads out into the final exhibit area, with a dig site and field laboratory station positioned before a final display of taxidermy-mounted South African mammals. In the dig space, a computer tablet is used to scan the landscape, to lead you to a "fossil" to excavate, and to ask questions about taxa (hominin vs. other) and the appropriate dating technique for your find.

Bringing original hominin fossils to Dallas is not creating the controversy that bringing the "Lucy" remains to Houston did. There are several likely reasons for this.
First, a curator associated directly with the Rising Star project is in residence at the museum. The advertisement for the exhibit states "One venue. One time." Second, a public announcement of the research opportunity at the museum was made in advance of the opening of the exhibit, with an open call for applications. Graduate students were especially encouraged to apply. Third, the remains are from South Africa rather than East Africa; the paleoanthropological politics are therefore different, as are the governments of the countries involved. Fourth, the remains of Homo naledi are numerous and no one fossil of either Homo naledi or Au. sediba is an icon in the way that the personified "Lucy" is. The fact that both Homo naledi and Au. sediba are considered "side branches" of our lineage may also be relevant. Finally, the politics of paleoanthropology have changed to some degree in the interval between 2007 and 2019 . While there are still several dominant personalities, there are many younger researchers and more of them work in large teams rather than alone or in small groups. Study of the fossils is therefore more widely distributed, including among researchers located in different countries who coordinate their research with one another on a regular basis, made possible in part by increased electronic communication.

\section{The Fort Worth Museum of Science and History}

Over in the sister city of Fort Worth, the natural history museum has no human evolution content. Furthermore, the word "evolution" does not appear, or at least I have not seen it in the museum in a biological context. Prior to the recent redesign of the dinosaur area, a tree diagram (loosely speaking, a cladogram) was displayed on one wall. Geologic dates, eras, and periods are clearly displayed in several locations. While the museum retains its signature DinoDig in an outside area, the excellent inside learning lab designed in conjunction with paleontologist Dr. Louis Jacobs of Southern Methodist University has been replaced by a dramatic staged scene with an Allosaurus taking down a Camptosaurus, high-tech visual imagery, and artistically arranged fossils and casts. In DinoStomp, you can insert yourself on the screen with various dinosaurs by standing in the correct location; in an inside area behind this large screen, you can draw a dinosaur (or whatever you want), scan it, and project your artwork. In 2018, a much-heralded DinoGlow multi-colored Stegosaurus went on display. According to the website (Fort Worth Museum of Science and History http://www.fwmuseum.org), "This Stegosaurus is a canvas where your imagination will take flight, with colors and textures at your fingertips on a touchscreen control."

The museum's primary focus is on children. (I was once asked if I was aware of this when purchasing a 
ticket.) Displays with Clifford the Big Red Dog, Dora and Diego, and Curious George have cycled through the museum in the past few years. An Exploratoriumstyle area typical of science centers occupies a large part of the first floor, and there is another area for young children. The Fort Worth Museum of Science and History is affiliated with a school founded 70 years ago (1949). The museum began as a children's museum associated with the school, so in some ways, under the leadership of a former Disney executive, the museum is returning to its roots. Museum president Van Romans spearheaded a museum expansion, with a new building that opened in 2009.

Another focus is on Fort Worth ranching history; the museum is located next to the National Cowgirl Museum and Hall of Fame and across the street from the Will Rogers Memorial Center. Although the ranching area is not primarily intended for children, there are some talking portraits of cattle and other elements to keep kids entertained.

The museum does have many events and talks for adults, including some relevant to paleoanthropology. Several years ago, I attended a talk on Dmanisi by Dr. David Lordkipanidze. In October of 2019, two archaeologists were featured in a "celebrity lecture" on the Gault site, a site with pre-Clovis lithics located in central Texas. The moderator for the evening event was the Director of Scientific Presentation, a scientist with a $\mathrm{PhD}$ in Astrophysics and Planetary Science who helped to design the museum's Launchpad exhibit about Apollo 11. With this recent hire (2017), the museum may be signaling a move toward astronomy, along with tech-heavy displays.

As part of a broader project, I have conducted interviews with museum curators and staff. Mr. Charles Walter, now at the Mayborn Museum in Waco, Texas, was formerly the Vice President of Interpretation at the Fort Worth Museum of Science and History. During his interview, he assured me that the reason the Fort Worth museum has no human evolution content has nothing to do with politics, at least Texas politics. The museum had an NSF grant to develop the dinosaur learning lab components. They were counseled by NSF personnel, among others, not to display dinosaurs and human evolution within the same area of the museum. Being constrained in space, they concentrated on dinosaurs. As Mr. Walter told me, "a dinosaur walked in our door" (with human assistance, of course). The original impetus for the entire project in conjunction with SMU paleontologist Dr. Louis Jacobs was an enquiry from a father and his son who brought a dinosaur fossil to the museum. That event was leveraged into a major new opportunity for the museum.
At one point Mr. Walter was interested in developing a traveling exhibit on Dmanisi; he could not gain traction on this, not finding sufficient interest in focus groups. Furthermore, the political situation in Georgia deteriorated vis-à-vis Russia during the planning period. The exhibit never materialized.

Fort Worth does have a statement on evolution that is available upon request. While not mentioning human evolution explicitly, the statement affirms that the museum "supports the position that evolution is a major unifying concept of science" and that the museum "utilizes scientific evidence in its presentation and interpretation of how life has changed over time." There have been substantial changes at the museum in the last several years. Many of these changes might be viewed negatively by academic (and some museum) professionals, but these changes more likely have to do with money than directly with politics.

\section{The Witte Museum}

San Antonio's Witte Museum underwent renovation recently. What is now called the "new Witte" opened in 2017 (Witte Museum http://www.wittemuseum.org). While there is no human evolution in the permanent galleries, the museum emphasizes "Deep Time." A display on the ground floor does a good job showing stratigraphy and taking visitors back in time from hundreds to thousands to millions of years ago. This is arguably necessary because the museum now has dinosaurs on the ground floor, an addition that does not fit seamlessly with the rest of the museum's exhibits.

When I visited in August 2019, two temporary exhibits were on display. One was an art exhibit, complete with staff to monitor visitors in a tranquil space typical of an art museum. The other temporary exhibit was Survival. Homo erectus is mentioned in connection with fire and cooking, both in the Survival exhibit itself and on one panel advertising this exhibit outside the museum. This was the only human evolution content I discovered in the museum.

Located in an outside area and a two-story exhibit in a second building, the H-E-B Body Adventure has the laudable goal of improving the health of San Antonio residents. One highlight of the exhibit is a large computerized anatomy table staffed by museum personnel and volunteers.

A new Pecos Peoples gallery is located on the second floor of the museum. Following a major donation in 2017, the museum now has a focus on rock art. One learning space includes a program teaching the basics of making paint from natural plant and animal materials; others teach additional archaeological concepts, including radiocarbon dating. A video in a simulated cave theater 
includes a comment by Curator of Archaeology Dr. Harry Shafer that he wants people to understand that these people 4000 years ago were just like us, with similar emotions, etc. It struck me that people would need to be told or reminded of that. For those of us accustomed to thinking regularly in millions of years, a few thousand years seems trivial in comparison. We may take it for granted that everyone shares this perspective, but an understanding of "Deep Time" is among the most diffcult, and important, concepts we can convey. The Smithsonian Natural History Museum's new fossil hall, in fact, is named Deep Time in recognition of the importance of this concept. Thus while the Witte Museum does not teach visitors about human evolution, it does prepare them for evolutionary thinking through its focus on different segments of time.

\section{The Texas Memorial Museum}

Of the five museums surveyed here, the Texas Memorial Museum is the only one associated with a university. It is located on the campus of the University of Texas at Austin. However, the museum is no longer supported directly by the university, even though it is part of its administrative structure. In 2014, the museum became dependent on admission fees and effectively became a separate entity.

From 2007 until mid-2017, an exhibit entitled Explore Evolution occupied the fourth floor of the museum. This NSF-funded exhibit was displayed at several sites throughout the U.S. (Diamond 2006). Developed in collaboration with the Science Museum of Minnesota and Dr. Judy Diamond of the University of Nebraska, the exhibit contains seven components. The current director of the Texas Memorial Museum is Dr. Edward Theriot, whose diatom research is featured in the second component.

The sixth component of this exhibit covers human evolution as one example within the broader evolution exhibit. Although the original design of the human component focused heavily on genetics, the Texas Memorial Museum staff added Bone Clones skeletons of a chimpanzee and a human and used these in associated youth and teacher workshops, required originally by NSF as a condition of funding the exhibit. On occasion, UT Austin faculty would assist with events or workshops. Many school groups also visited the exhibit as part of their trip to the museum.

Through the years, due to lack of sufficient funding, the exhibit deteriorated to some degree. This was most notable in the audio-visual elements of the exhibit, many of which no longer worked by my first visit in 2016. The space occupied by this exhibit on the fourth floor of the museum is among the most flexible spaces within the museum, making it an ideal location for temporary exhibits. Once the museum, formerly free, had to support itself with admission fees, it needed to develop new exhibits to bring in customers who otherwise might not pay to visit. (Parking on the UT campus also entails costs. It is impossible to overlook the fact that the museum is directly adjacent to the massive UT football stadium, with which it shares a parking garage.)

The museum director expressed concern that some school groups and other visitors, based on anecdotal accounts, would not go to the fourth floor because of the evolution content (personal communication). It is important to note that no direct data were collected by the Texas Memorial Museum staff on the percentage of visitors who indicated this reason for not visiting this exhibit. At any rate, I would argue that this content concern was overshadowed by the pressing monetary concern in this case. The Explore Evolution exhibit was old and it occupied a space suitable for new exhibits with the potential to attract more paying customers. The museum has other evolution content on the ground floor in a display of Texas environments and fossils through geologic time. Austin is politically liberal, and the museum is located on the campus of UT Austin. The museum is not shy about promoting evolutionary science.

The Explore Evolution exhibit was taken out and replaced by a temporary, traveling exhibit on Helicoprion ("buzz-saw") sharks in 2017. Today, according to the museum's website (Texas Memorial Museum http://tmm. utexas.edu), "The main gallery on the fourth floor is temporarily closed." While the first floor has prominent evolution content in its Texas paleontology area, it remains to be seen if human evolution content will reappear in the museum in the future.

\section{Discussion: Why do the differences among these museums exist?}

The first, and most important, point is that both Houston and Dallas, the two largest population centers, have human evolution exhibits. As the title of this article proclaims, Texas is not a human evolution desert!

This survey of Texas museums is part of a larger project that includes seven U.S. museums outside of Texas and the Natural History Museum in London. When I began the project, I was suspicious that politics might directly or indirectly influence the content of exhibits in Texas museums. On the one hand, I have found reassurance that there is little to no direct influence. On the other hand, many museums are under more funding stress than I would have predicted. Politics matters, but I would argue that it matters mostly in connection with funding.

Despite the overall politics of the state, as elsewhere in the country, there is a rural-urban divide. Dallas, 
Houston, and San Antonio are typically "blue." Tarrant County, the county in which Fort Worth is located, is atypically "red" for a county containing such a large urban population. However, the museum content differences between the Perot and the Fort Worth Museum of Science and History, located within the same metropolitan area, do not appear to be related to this political distinction. In connection with an NSF grant, the Fort Worth museum formerly trained teachers in paleontology. Both the Dallas and Fort Worth museums had their strongest science centered on dinosaur paleontology. A major infusion of cash, associated with museum mergers, created the current version of Dallas' natural history museum; the resulting Perot Museum is part natural history museum and part science center. The Fort Worth Museum of Science and History hired a new president, a former Disney executive, in 2004 (Whiteley 2004). Under his leadership, the museum expanded. The indoor dinosaur area has now been renovated to focus less on teaching science and more on aesthetics and graphics technology. Like many museums, the Fort Worth museum works hard to be relevant to the community. While the displays are mostly aimed toward children, there are events for adults, some held off-site at local taverns. The Perot similarly endeavors to be relevant to patrons of all ages, holding comparable events.

In Houston, a lone archaeologist curator is charged with oversight of nearly all content related to anthropology throughout the museum. In addition to the Morian Hall, the Hall of the Americas has content related to the most recent period of human paleoanthropology (i.e., the colonization of the New World). Much of the Morian Hall's human-focused content is dedicated to the archaeology of Texas. Dr. Michael Collins of Texas State University, the lead archaeologist for the excavation of the important Paleoindian Gault site in Texas, was a consultant on this material.

Most museums have a mission of highlighting local finds. These museums have limited resources and need to make a connection for people to something they know and care about. The U.S. has no human sites deriving from deep prehistory, which makes the U.S. museum experience different from that in Africa, France, or even England. Rarely do U.S. museums display original skeletal material. (Exceptions include "Magdalenian woman" at the Field Museum and the Shanidar 3 Neanderthal at the Smithsonian.) For ethical and security reasons, in most cases casts or reproductions will be placed on display. In fact, in many cases original fossils, even when owned by museums, are not placed on display in the museums that hold them. This is in part why bringing the "Lucy" remains to Houston was so controversial; in Ethiopia, the original fossils were not on display, being made available only to qualified researchers by prior arrangement.

In the U.S., there is the challenge of making human evolution more interesting to the museum-going public than dinosaur evolution. While to those of us who study human evolution this would appear to be an easy taskit's our story, after all-dinosaurs have been marketed very well for the past 100 years and are an American institution of sorts (Rieppel 2019). Texas has been the site of major dinosaur discoveries. Dr. Louis Jacobs formerly studied fossil rodents and early primates; discoveries in the Dallas-Fort Worth area prompted a change in his focus. Recall Mr. Walter's remark regarding a dinosaur "walking in the door" at the Fort Worth Museum of Science and History: they had a better dinosaur story to tell (personal communication). It's all about the narrative. You need a good story to tell.

In deciding on the narrative, the goals and vision of the museum curators and staff, and often external designers from hired firms, shape the content. Explore Evolution was not intended to be primarily about human evolution, but it was essential not to omit humans. The Perot's narrative has a strong connection to medical research due to established relationships with UT Southwestern researchers. Each museum has a unique history and mission, and its exhibits will be shaped by the people and firms the museum hires, consistent with its mission.

The Perot Museum's Being Human Hall is newly renovated, and the Perot has decided to make human evolution the focus of a new Center, seeing an opportunity to expand in a content area for which funding was available and a niche was open. Public interest had been demonstrated by Dr. Lee Berger's talks at the museum, and the Dallas philanthropist Ms. Lyda Hill is a major donor for both the Perot Museum and the Rising Star project. Crediting Mr. Walter again for this point, intentionality matters. Museums make decisions intentionally, sometimes, that take them into new areas. For the Perot, one such decision has been a new focus on human evolution, especially South African human evolution. For the Witte, it has been dinosaurs and "Deep Time" on the one hand and Pecos Peoples and rock art on the other. In both of these cases, perceived public interest and available donors helped direct these decisions. Opportunities that present themselves are seized upon because they are judged to benefit the museum.

In the end, it comes down, unsurprisingly, to money. Most museums have tight budgets, even those that have substantial admissions fees. They expend a large amount of effort trying to convince visitors to become members who will continually provide support. Some museums are in danger of not being able to continue to fund basic operations. The Texas Memorial Museum is among those 
in this category. Exhibits get outdated and technology ceases to function and cannot be replaced. Something new is needed to keep visitors, the paying customers, coming in. The San Diego Museum of Man's Footsteps through Time exhibit, opened in 2002, was among the best human evolution exhibits in the country prior to its closure in 2018 (San Diego Museum of Man http:// www.museumofman.org). There are no immediate plans to replace this content, and it is unclear whether the museum will ever again cover human evolution, beyond the human biology content of its Race: Are We So Different? exhibit.

Politics does matter, but in an indirect way, filtered through the more immediate monetary bottom line. In Texas, there are fantastic energy exhibits, including the brand new Wiess Energy Hall in Houston, occupying a full floor of the museum. At 30,000 square feet, it occupies as much space as does the Morian Hall of Paleontology, being "almost the size of a football field." (Wiess Energy Hall http://www.hmns.org). If our goal is to see human evolution content presented more commonly and more comprehensively in U.S. museums, then we will need to convince museum administrators that such displays will help their bottom line.

\section{Conclusion: What can we do to promote human evolution museum displays?}

Museum displays need to entice and inspire people, including children, as well as contain information that is inherently significant and relevant for the public to know. Major donors must be sold on the proposals. Even if museums are non-profit and have worthy educational goals, they have visitors who are also customers and who could choose to do other things with their leisure time. There must be interesting stories to tell, with personal connections, and there must be substantial financial backing, in order for human evolution exhibits to be successful.

Many modern museums rely on traveling exhibits to keep members and other repeat visitors coming back regularly. One strategy, therefore, would be to create traveling exhibits containing human evolution content. The Race: Are We So Different? exhibit, produced by the Science Museum of Minnesota in collaboration with the American Anthropological Association, has some biological anthropology and evolutionary principles included in it. Dr. Nina Jablonski's Skin: Living Armor, Evolving Identity exhibit at the California Academy of Sciences (Skin http://www.calacademy.org) is currently an in-house exhibit, but it, or something similar, could be developed to travel. Exhibits on DNA and ancestry and ones on evolutionary medicine (e.g., Pickering et al. 2012) that would attract visitors could be developed. All these examples connect human evolution to topics relevant to people in their lives today. The Smithsonian Natural History Museum's recent positive experience with a traveling exhibit on human evolution, Exploring Human Origins: What Does It Mean To Be Human? (Human Origins http://humanorigins.si.edu), indicates that communities throughout the U.S. are more likely to be receptive to human evolution exhibits than many would have predicted.

Furthermore, as museums such as the Perot dedicate resources to human evolution and attract visitors to their exhibits, it will be easier to convince other museums that the topic is worth the investment. Climate change has become a "hot" topic in science museums; far from shrinking from controversy, museums that may have avoided this topic in the past will not hesitate to display content if audience research indicates an interest among their patrons. In a similar way, biological anthropologists can engage with their local museums to promote human evolution as a topic. An easy entrée is through offers to give public lectures. As museum administrators discover the potential of human evolution to engage audiences, they will be better equipped to convince their boards and donors of an emerging opportunity.

Finally, it is unrealistic to expect human origins displays to start popping up in large numbers in local museums nationwide. There are nevertheless opportunities to introduce key ideas that will help our future students. A good example is teaching about "Deep Time" in any paleontology exhibit. Several museums now also employ the "how do we know?" theme to reinforce scientific methodologies. In health-related exhibits, it would likewise be helpful if evolutionary concepts could be introduced into the teaching of basic human biology. Well-trained docents and volunteers are of considerable value in this context. We can encourage our students to volunteer in local museums or become museum interns, perhaps for university credit. The students, the museums, and the public would all benefit from such collaborations.

\section{Acknowledgements \\ The content of this article reviews a small part of the data collected for a pro- ject of greater scope. I thank all of the curators and museum staff who have graciously given their time for interviews. In particular, for Texas museums, I acknowledge the following individuals: Drs. Louis L. Jacobs, Rose Jones, Mr. Dan Kohl, Ms. Pamela Owen, Drs. Becca Peixotto, Edward C. Theriot, Dirk Van Tuerenhout, and Mr. Charles H. Walter. I acknowledge with gratitude funding through various UT Arlington sources for multiple phases of this project. Finally, I thank the two anonymous reviewers for their excellent suggestions for revision of the original manuscript.}

\section{Authors' contributions}

This is a sole-authored work (S.L. Smith). The author read and approved the final manuscript.

Funding

University of Texas at Arlington. Note: The majority of the funding was for travel to museums outside of Texas, beyond the scope of this manuscript. 
Availability of data and materials

Data are not available. Data are qualitative (interviews and personal notes) and are being used for an in-progress monographic treatment of a larger project.

\section{Ethics approval and consent to participate}

The University of Texas at Arlington reviewed this research and ruled the interview data exempt.

\section{Consent for publication}

Not applicable.

\section{Competing interests}

The author has no competing interests.

Received: 29 October 2019 Accepted: 14 February 2020

Published online: 18 February 2020

\section{References}

Berger E. Lucy gets here safely, but debate over display rages. Houston Chronicle. http://www.chron.com. 2007. Accessed 13 Oct 2019.

Breal J. An interview with Dirk Van Tuerenhout. Texas Monthly. http://www. texasmonthly.com. 2007. Accessed 13 Oct 2019.

Collins G. How Texas inflicts bad textbooks on us. http://www.nybooks.com. 2012. Accessed 13 Oct 2019

Curnoe D. A review of early Homo in southern Africa focusing on cranial, mandibular and dental remains, with the description of a new species (Homo gautengensis sp. nov.). Homo. 2010;61:151-77.

Davis W. Building an ark for Texas: the evolution of a natural history museum. College Station: Texas A\&M University Press; 2016.

Daynès E. http://www.daynes.com. Accessed 20 October 2019.

Diamond J, editor. Virus and the whale: Exploring evolution in creatures small and large. Arlington: NSTA Press; 2006.

Driver A. Texas museum to show Lucy fossil amid criticism. Reuters. http:// www.reuters.com. 2007. Accessed 13 Oct 2019.

Fort Worth Museum of Science and History. http://www.fwmuseum.org. Accessed 13 Oct 2019.
Human Origins, Smithsonian Natural History Museum. http://humanorigins.si. edu. Accessed 13 Oct 2019

Miller JD, Scott EC, Okamoto S. Public acceptance of evolution. Science. 2006;313:765-6.

Paul Bernhard Exhibit Design, Morian Hall of Paleontology. http://www.pbexh ibits.com. Accessed 15 Oct 2019.

Perot Museum of Nature and Science. http://www.perotmuseum.org. Accessed 13 Oct 2019.

Pickering J, Fawcett L, Munstermann L. An alternative approach: teaching evolution in a natural history museum through the topic of vector-borne disease. Evo Edu Outreach. 2012;5:62-7.

Rhor M. "Lucy" exhibit worries some scientists. Associated Press. http://nbcne ws.com. 2007a. Accessed 13 Oct 2019.

Rhor M. Lucy makes curator target of criticism. Associated Press. http://washi ngtonpost.com. 2007b. Accessed 13 Oct 2019

Rieppel L. Assembling the dinosaur: Fossil hunters, tycoons, and the making of a spectacle. Harvard University Press; 2019.

San Diego Museum of Man. http://www.museumofman.org. Accessed 27 Dec 2019.

Skin: Living armor, evolving identity, California Academy of Sciences. http:// www.calacademy.org. Accessed 15 Oct 2019.

Texas Freedom Network. http://www.tfn.org. Accessed 21 December 2019.

Texas Memorial Museum. http://tmm.utexas.edu. Accessed 13 Oct 2019.

U.S. Census. http://www.factfinder.census.gov. July 1, 2018 estimates. Accessed 1 Sept 2019.

Whiteley M. Fort Worth science museum hires Disney veteran. Dallas Business Journal. http://www.bizjournals.com. 2004. Accessed 15 Oct 2019.

Wiess Energy Hall, Houston Museum of Natural Science. http://www.hmns.org. Accessed 15 Oct 2019.

Witte Museum. http://www.wittemuseum.org. Accessed 13 Oct 2019.

\section{Publisher's Note}

Springer Nature remains neutral with regard to jurisdictional claims in published maps and institutional affiliations.
Ready to submit your research? Choose BMC and benefit from:

- fast, convenient online submission

- thorough peer review by experienced researchers in your field

- rapid publication on acceptance

- support for research data, including large and complex data types

- gold Open Access which fosters wider collaboration and increased citations

- maximum visibility for your research: over $100 \mathrm{M}$ website views per year

At BMC, research is always in progress.

Learn more biomedcentral.com/submissions 